\title{
Die Judasbrief: 'n Simboliese universum in die gedrang
}

SJ Joubert

\section{Abstract}

The letter of Jude: A symbolic universe endangered

The readers to whom Jude adresses his letter experience alienation from their symbolic universe because of their contact with certain people who hold a different interpretation of God. Within the letter's textworld Jude maintains his reader's symbolic universe by changing their image from that of a weak group to a strong group with a clearly defined status and role. He also presents their worid as an ordered whole and as the only legitimate form of existence where God protects those who obey his commands and punishes those who place themselves outside the readers' symbolic universe through their conduct.

Die Judasbrief kan met reg die stiefkind van die Nuwe Testamentiese briefliteratuur genoem word. Weinig ondersoekers bemoei hul vandag nog intensief met die vraagstukke van dié kort briefie. Die rede vir hierdie toedrag van sake is moeilik verklaarbaar, maar waarskynlik hou dit verband met die feit dat die vernaamste probleme waarmee die Judasbrief die Nuwe Testamentiese wetenskap in die verlede gekonfronteer het, tans in ' $n$ groot mate tot bevrediging van die meeste navorsers opgelos is. Daar bestaan byvoorbeeld oor 'n wye spektrum eenstemmigheid dat die dwaalleraars waarna in die Judasbrief verwys word libertiniste was wie se algemene gedrag belangrike ooreenkomste met die tweede eeuse gnostisisme vertoon (Rowston 1975: 561-2; Hahn 1981: 212; Frankemölle 1987: 125). Dit word deesdae ook redelik algemeen aanvaar dat hierdie brief aan Joodse Christene binne 'n heidense milieu geskryf is (Bolkestein 1963: 221; Eybers 1975: 114; Bauckham 1983: 16), dat dit teen die einde van die eerste eeu nC geskryf is (Reicke 1978: 192; Kümmel 1979: 429), dat Judas en 2 Petrus groot ooreenkomste ten opsigte van woordgebruik en volgorde in die aanbieding van stof vertoon en dat 2 Petrus (as latere van die twee briewe) in dié opsig van Judas gebruik gemaak het (Kelly 1977: 227; Grundmann 1979: 2; Conzelmann \& Lindemann 1982: 322), ensovoorts. 
Hierdie artikel wil nie bogenoemde bevindinge bevraagteken of daarop uitbrei nie. Veel eerder wil dit poog om sommige van die nuwe insigte wat die antroplogogie, sosiologie (meer besonderlik die kennissosiologie en die sosio-linguistiek) en die literêre kritiek ten opsige van die verstaan van tekste en lewenswêrelde onder die Nuwe Testamentiese wetenskap se aandag gebring het op die Judas teks toe te pas en vas te stel hoe Judas 'n bepaalde bedreiging van sy lesers se simboliese universum binne die tekswêreld van die brief hanteer het. Aspekte soos: Die aard en inhoude van die simboliese universum wat Judas en sy lesers handhaaf, die rolle wat die betrokkenes by hierdie simboliese universum binne hul leefwêreld vervul, die verhouding tussen die lesers se interpretasie van die realiteit en hul gepaardgaande optrede met betrekking tot die dwaalleraars (soos wat die persone wat die lesers se universum bedreig het voortaan aangedui sal word) wat in die brief vermeld word, die dwaalleraars se verstaan van God en die bedreiging wat dit vir die lesers se simboliese universum ingehou het, Judas se handhawing van die bedreigde simboliese universum, ensovoorts, dien hulle self byna outomaties as objekte van ondersoek binne 'n analise van dié aard oor die Judasbrief aan. Uit die aard van die saak loop so ' $n$ ondersoek ' $n$ eie pad omdat dit eiesoortige aannames, probleemstellings, metodologiese- en interpretasieprobleme en konklusies na vore roep (alhoewel hierdie benadering by geleentheid wel paaie kan kruis met die reeds uitgetrapte paaie van die historieskritiese ondersoeke na die Judasbrief). Hopelik sal dit 'n bydrae lewer tot die sinvolle opening van nuwe roetes met betrekking tot die interpretasie van Nuwe Testamentiese tekste in die algemeen en die Judasteks in die besonder, asook tot 'n nuwe verstaan daarvan.

\section{TEKSWÊRELD, LEEFWÊRELD EN SIMBOLIESE UNIVERSUM}

Alle informasie wat die skrywer van 'n brief aan sy lesers kommunikeer, word in ' $n$ binnetekstuele gespreksituasie tussen 'n binnetekstuele of implisiete outeur en lesers aangebied. Die vorm waarin hierdie gesprek aangebied word sowel as die inhoud daarvan kan as die tekswêreld van die brief omskryf word. Genoemde tekswêreld bestaan met ander woorde uit al die vermelde semantiese informasie wat in bepaalde grammatiese verhoudings binne die brief tot mekaar staan, maar ook uit al die implisiete semantiese komponente wat uit die vermelde tekstuele gegewens afgelei kan word. Dolezel (1985: 193) merk 
in dié verband heel tereg op dat 'n tekswêreld '.. . is constructed not only by explicit (manifest) components of the text, but also - and sometimes quite significantly - by its implicit semantic constituents...'

Die tekswêreld bring die sosiale interaksie tussen die reële outeur en sy lesers binne 'n spesifieke leefwêreld, (wat omvat word deur 'n simboliese universum), sowel as die interaksie tussen genoemde persone en ander mense of groepe wat in die brief vermeld word - wat ook hulle eie leefwêreld en simboliese universum kan hê - (gedeeltelik) onder woorde. Oor die feit dat die Judasbrief ekstratekstueel refereer (soos wat dit onder andere blyk uit die intensie van die sender of implisiete outeur asook uit die resepsiegeskiedenis van die teks waarop in hierdie artikel nie ingegaan kan word nie) kan daar seker nie veel twyfel bestaan nie. ' $n$ Meer ter sake vraag sou egter wees op welke wyse dit na die werklikheid verwys. Ter beantwoording hiervan moet benadruk word dat die tekswêreld geen reproduksie of immitatio van die realiteit kan wees nie aangesien dit slegs sekere informasie uit die teksenterne realiteit selekteer en ooreenkomstig bepaalde konvensies in 'n nuwe kombinasie van patrone aanbied. 'Die buitewêreld word immers nooit bloot in die teks herhaal nie, maar juis beskryf, geïnterpreteer, geskep...' (Du Toit 1987: 162). Elemente uit die wêreld agter die teks, soos plekke (Sodom en Gomorra), persoonsname (Judas, Jakobus, God, Henog), gebeure, temas, motiewe, tradisies, ensovoorts, wat aan die skrywer en lesers bekend is, word met ander woorde nou in 'n nuwe relasie, maar ook in kontras met, ander linguistiese tekens gebruik om nuwe betekenisse te genereer (vgl ook Sorensen 1970: 70-3). Uiteraard skep hierdie daad van opskrifstelling ' $n$ groot mate van afstand of Vervremdung '...from the author, from the situation of discourse, and from the original audience...' (Lategan 1985a: 23), omdat dit die gedagte van 'n een-tot-een verhouding tussen die linguistiese tekens en hulle referente (dit wil sê, die sake of denotata waarna hulle telkens verwys) deurbreek. Hierdie afstand, maar ook die aanbieding van reeds bekende tekens in 'n nuwe volgorde, skep terselfdertyd egter ook die moontlikheid tot ' $n$ herinterpretasie van die realiteit. Dit open met ander woorde die weg na die 'world in front of the text' (Ricoeur 1978: 220). Referensie figureer dus gelyktydig op meer as een vlak. Buiten die (indirekte) verwysing na die ekstra-tekstuele referente, verwys dit ook na bovermelde nuwe wêreld voor die teks en na 'n gepaardgaande nuwe bestaansmoontlikheid wat dit vir die lesers daarvan open.

Die tekswêreld van die Judasbrief gee dus nie alleen maar net aan ons 
'n algemene idee van hoe die omstandighede wat aanleiding tot die skrywe gegee het daar uitsien nie (vgl in dié verband afd 2), maar ook hoe die 'realiteit' waartoe die skrywer sy lesers eventueel wil beweeg, lyk (vgl afd 6). Die beweging (van die kommunikasie) is dus as't ware van binne na buite die teks. Taal funksioneer by uitstek in hierdie konteks in ' $n$ oorredende verband om 'n gegewe interpretasie van die realiteit en kennis hiervan oor te dra (Douglas 1975: 85; McGaan 1980: 48). Alle informasie wat binne die tekswêreld van die Judasbrief aangetref word, sowel as die wyse waarop dit weergegee word, word immers met die doel aangebied om 'n bepaalde respons by die lesers te bewerkstellig, hetsy '... as provoking either immediate action, the making of a decision, or a commitment to act...' (Perelman 1979: 11). Taal verskaf in hierdie verband dan die inligting en rasionaal waarom die lesers op 'n gegewe wyse moet optree; dit verskaf ook die redes $\therefore$...why it makes sense or can be to one's benefit to act or not to act. Influence (by persuasion) thus looks to change opinions and attitudes so that intended actions might follow...' (Malina 1986: 80).

Die implisiete outeur, as organiserende instansie (Van Coller 1985: 71) wat ons leer ken uit al die tekstuele aanwysings wat die implisiete lesers onderrig hoe om die teks te lees, word eksplisiet as Judas aangedui. Judas figureer binne die brief as 'n significant other (dit wil sê, as ' $n$ belangrike identifikasiemedium met wie sy lesers kan identifiseer). 'n Significant other is veral verantwoordelik vir die sosialisasie van individue, in hierdie geval die lesers van die Judasbrief, binne die leefwêreld (vgl die volgende paragraaf) waarin hulle hulleself bevind. Om hierin te slaag, verhef hy (as teksinterne outeur) nou sy eie definisie van die realiteit tot die enigste basis vir die legitieme eksistensie van sy lesers. Sy interpretasie neem dus die gestalte van die 'objektiewe realiteit' vir laasgenoemde aan, as die normale wyse hoe dinge behoort te geskied (vgl ook afd 6).

Die tekswêreld bring ook die spesifieke leefwêrelde waarbinne die verskillende persone wat binne die Judasbrief vermeld word, bestaan, onder woorde. Terwyl die begrip tekswêreld 'n meer omvattende term vir die vorm sowel as die inhoud van die brief is, dui leefwêreld hier op die bepaalde realiteit of sosiale orde waarbinne die reële persone wat binne die brief vermeld word (dit wil sê, Judas en sy lesers aan die een kant en die dwaalleraars aan die ander kant) hulself onderskeidelik bevind. Die bestaan van enige sosiale orde is die gevolg van 'n proses van bewoonbaarmaking ('habitualization' - Berger \& Luckmann 1975: 53) van die omgewing waarbinne mense hulle self bevind, wat op sy 
beurt weer aanleiding gee tot die institusionalisering daarvan. Institusionalisering behels dat menslike gedrag binne sodanige groep wat nou tot stand kom onder sosiale beheer en kontrole geplaas word en dat duidelike gedragspatrone aan die bepaalde rolle wat hierbinne voorkom, gekoppel word. Hierdie wêreld word op sy beurt deur 'n proses van legitimasie subjektief verstaanbaar en geldig gemaak vir die individue hierbinne, waarvan die skepping van 'n simboliese universum (as die basis vir alle korporatiewe aktiwiteite van die groepslede) die mees omvattende en belangrikste vorm is. Volgens Berger en Luckmann (1975: 114) se omskrywing van 'n simboliese universum integreer dit alle sektore van die geïnstitusionaliseerde orde in

... an all-embracing frame of reference, which now constitutes a universe in the literal sense of the word, because all human experience can now be conceived of as taking place within it. The symbolic universe is conceived of as the matrix of all socially objectivated and subjectively real meanings; the entire historic society and the entire biography of the individual are seen as events taking place within this universe.

Omdat die totale sosiale orde en alle vorme van betekenis hierbinne in 'n simboliese totaliteit omvat word, dien dit as die vernaamste wyse waarop ' $n$ bepaalde gemeenskap se eksistensie gelegitimeer word. 'n Simboliese universum is dus die finale stap in die sosiale konstruksie van die realiteit deur sodanige gemeenskap waardeur die gegewe (en 'ongeordende') werklikheid waarmee hulle gekonfronteer is, geïntegreer en sinvol gemaak is. Volgens Hamilton (1974: 141) het die meer tradisionele term wêreldbeeld (Weltanschauung) ongeveer dieselfde betekenis as simboliese universum. Tog wil dit voorkom asof eersgenoemde term meesal in 'n geografies-etnies bepaalde verband gebruik word ter beskrywing van die realiteitsbeskouinge van kulturele groepe (Kraft 1979: 53), maar ook as uitdrukking van die heersende wetenskaplik-filosofiese persepsie van 'n bepaalde tyd (Merrell 1986: 131-2).

Uiteraard impliseer die bestaan van ' $n$ bepaalde simboliese universum dan die bestaan van 'n groep individue wat dieselfde opvattinge oor die realiteit deel. Hierdie gemeenskaplike interpretasie van die werklikheid is (soos reeds gesê) die gevolg van 'n proses van internalisasie of subjektiewe integrering van sekere fasette van die objektief gegewe realiteit wat eventueel dan lei tot die ontstaan van 'n bepaalde groep of gemeenskap met 'n eie leefwêreld, wat op sy beurt weer deur 'n simboliese universum gelegitimeer word. Die simboliese universum 
verleen stabiliteit aan individue binne hierdie groep aangesien dit alle vlakke van die realiteit in ' $n$ betekenisvolle geheel integreer en aan die mense hierbinne 'n veilige bestaansruimte bied. 'It puts everything in its right place ...' (Berger \& Luckmann 1975: 116). Dit stel groepslede ook in staat om die instellings van die breëre samelewingsverbande rondom hulle aan die hand van hul groepsnorme te evalueer.

\section{TEKSWÊRELD EN REALITEIT}

Tekste is die produkte van 'n bepaalde sosiale gemeenskap wat op hulle beurt weer in diens van hierdie gemeenskap staan (Kee 1980: 129). Die moeilike, en tot op hede nog onopgeloste vraag binne sosiologiese ondersoeke na die Nuwe Testamentiese literatuur is egter hoe om van tekste na die sosiale realiteite wat hierin weerspieël word te beweeg (Scroggs 1980: 176; De Villiers 1982: 26; Best 1983: 182-3). Omdat hierdie studie dit nie as primêre oogmerk het om antwoorde op die genoemde vraag te probeer verskaf nie, maar om eerder aan te toon hoe die bedreiging van ' $n$ simboliese universum binne ' $n$ bepaalde tekswêreld hanteer word, word slegs met 'n paar kursoriese opmerkings in dié verband volstaan. Die rede waarom hierdie takie egter wel onderneem word, is omdat dié gekonstrueerde beeld as die dekor (Vorster 1984: 113) of raamwerk dien waarteen die brief inhoudelik gelees kan word.

Indien ons dan die situasie waarin die reële lesers hulle bevind het kortliks wil konstrueer, dien die gegewens wat binne die Judasbrief vermeld word (vanweë die feit dat dit ook indirek na die ekstratekstuele realiteit agter die teks verwys), sowel as ander relevante literatuur soos die tweede Petrusbrief as die vernaamste bronne hiervoor. Die tweede Petrusbrief maak ruimskoots van temas en motiewe vanuit die Judasbrief gebruik (vgl bv Frankemölle 1987: 82-4) wat daarvan 'n belangrike inligtingsbron rakende die omstandighede waarna na Judas verwys, maak. Waarskynlik lyk die prentjie dan soos volg:

- 'n Bepaalde Christelike gemeenskap wat in die apostoliese tradisie gegrondves is, begin om ander persone, met sieninge wat vreemd aan hulle eie is, (maar wat hulle wel as Christene voordoen) binne hulle religieuse byeenkomste te akkomodeer (vgl ook 2 Pet 2: 13).

- Hierdie dwaalleraars leef losbandig omdat hulle glo dat God se genade groot genoeg is om hulle oortredings oor die hoof te sien (vgl 2 Pet $2: 10 ; 14 ; 18$ ). 
- Hulle beledig die engele en verwerp die inhoude van die apostoliese leerstellings (vgl 2 Pet 2: 10).

- Hulle beïnvloed mense binne die gemeente om hulle gedragswyses en hulle beskouinge te aanvaar.

Hierdie stand van sake gee dan aanleiding tot die skrywe van die Judasbrief waarbinne Judas poog om genoemde optrede van die dwaalleraars as strydig met God se wil uit te wys en die korrekte gedrag wat van die lesers in hierdie verband verwag word, uit te stippel.

\section{DIE BEDREIGDE SIMBOLIESE UNIVERSUM EN SOSIALE WÊRELD VAN DIE LESERS SOOS GEREFLEKTEER IN DIE TEKSWERELD VAN DIE JUDASBRIEF}

\subsection{Die simboliese universum}

Verskeie hemelwesens bevind hulle self binne die bedreigde simboliese universum wat in die Judasbrief vermeld word, en verskeie persone word binne die sosiale leefwêreld wat hierdeur gelegitimeer word, aangetref. Indien ons eerstens die simboliese universum van die lesers wil konstrueer, kom ons voor bepaalde probleme te staan aangesien die Judasbrief aan ons net die breë kontoere van hierdie simboliese universum en die gepaardgaande leefwêreld bied. Die skrywer vermeld immers net fasette hiervan wat relevant tot sy skrywe is. Verder word genoemde gegewens ook nog binne die beperkte (en beperkende) ruimte van die brief se tekswêreld ooreenkomstig die gekose uitgangspunte en interpretasie van die geïmpliseerde outeur aangebied. Alhoewel ons dan, vanweë 'n tekort aan inligting, ongelukkig nie 'n volledige beeld van dié bedreigde simboliese universum kan vorm nie, bied die skrywer tog voldoende informasie om minstens die raamwerk hiervan te konstrueer.

Judas meld dat God, Christus en die Heilige Gees, as bewoners van die simboliese universum, aan die hoof van die kerk of leefwêreld waarbinne hy en sy lesers hulle bevind, staan en maak dit duidelik dat hulle volkome beheer oor die verloop van gebeure hierbinne uitoefen. Hy dui God spesifiek as die Vader (vers 1) van die gemeente aan. Deur na God op hierdie wyse te verwys, word dieselfde tipe rolverwagtinge wat gewoonlik aan 'n vaderbeeld in die empiriese realiteit gekoppel word op Hom oorgedra. Volgens Judas tree God dan ook soos 'n tipiese 
vaderfiguur op omdat hy aan sy die lesers die lewe skenk deur Sy roeping en verlossing (vers $1 ; 25$ ). Dit is met ander woorde aan Sy toedoen te danke dat die lesers hulle self nou binne die nuwe leefwêreld bevind waar hulle God se vaderlike liefde ervaar (vers 2) omdat $\mathrm{Hy}$ hulle vanuit hul oneintlike bestaan hierheen oorgeplaas het. As Vader waarborg Hy ook hulle veilige bestaan binne die kerk tot aan die einde van die tyd (vers 24 ).

God staan volgens die outeur egter in ' $n$ oordelende verhouding jeens almal wat weier om hulle self aan Sy norme en reëls te onderwerp en hulle self sodoende buite die leefwêreld van Judas en sy lesers plaas. Hy noem dan ook verskeie voorbeelde van God se optrede jeens die buitestaanders in hierdie verband:

- Hy het lankal reeds ' $n$ oordeel vir die dwaalleraars wat die gemeente tans bedreig, voorberei (vers 4), en dit word vir hulle in die donker dieptes gereed gehou (vers 13).

- Hy vernietig diegene wat nie in Hom glo nie. In die verlede toe $\mathrm{Hy}$ sy volk uit Egipte verlos het, het Hy die ongelowiges onder hulle met die dood gestraf (vers 5).

- Engele wat hulle nie binne die sfeer gehou het wat God vir hulle bepaal het nie, bind $\mathrm{Hy}$ met onbreekbare kettings en hou hulle in die donker dieptes tot op die laaste oordeelsdag gevange (vers 6).

- Sodom en Gomorra en ander stede rondom hulle wat agter 'vreemde vlees' aangeloop het, word tans gestraf in die vuur wat vir ewig brand (vers 7).

- Almal wat goddeloos lewe sal op die groot oordeelsdag deur God gestraf word (vers 15).

God se oordeelsmag oor diegene wat hulle self deur hulle woorde en dade buite die sfeer van die lesers se leefwêreld en simboliese universum plaas, behels dan dat $\mathrm{Hy}$ hulle fisiese eksistensie termineer, soos wat $\mathrm{Hy}$ reeds in die verlede met vele ongelowige mense en engele gedoen het, en dat Hy hulle hierna binne 'n nuwe sfeer, wat onsigbaar vir die lesers is, plaas waar hulle vir ewig pyn en lyding sal ervaar. Hierdie sfeer word metafories as ' $n$ plek van pikdonkerte beskryf waar 'n ewige vuur brand. Op die laaste dag van die tydsbestek waarbinne die lesers hulself tans bevind, sal God vanuit sy onsigbare bestaansfeer die sigbare wêreld betree en alle goddeloses vir ewig na hierdie plek van vuur en donkerte verban.

God se heerskappy strek dus nie net oor die leefwêreld van die lesers nie, maar ook oor die ganse sigbare en onsigbare realiteit. Die rede 
hiervoor is omdat Hy die enigste God is (vers 25) wat oor absolute mag beskik. Daar bestaan geen teenmag naas Hom wat vir Hom 'n bedreiging sou inhou nie. As God is Hy ook nie aan die empiriese tydsverloop gebind of daarvan afhanklik nie omdat Hy dit geskep het en dit weer op 'n bepaalde dag in die toekoms sal ophef. Hy is immers van ewigheid af reeds God, en tot in ewigheid sal Hy ook alle mag (eksousia), krag (kratos) en heerlikheid (doxsa) behou (Jud 1: 25).

Christus word binne die tekswêreld van die Judasbrief as Kúrios en Meester van die lesers voorgehou (vers 4). Hy is hulle Kúrios omdat God se heil deur Sy bemiddeling (dit wil sê, Sy kruisdood en opstanding) by hulle uitgekom het (vers 24). As Here sal Hy ook aan die einde van die tyd met Sy verskyning alle gelowiges wat aan Hom getrou gebly het, oorplaas in 'n nuwe konflikvrye bestaanswyse, te wete die ewige lewe (vers 21). Daar bestaan 'n noue wisselwerking tussen God en Christus met betrekking tot die lesers se veilige voortbestaan binne hul leefwêreld. God bewaar naamlik alle gelowiges vir Christus (vers 1) tot op die laaste dag. Alhoewel die Nuwe Afrikaanse Vertaling genoemde uitdrukking in vers 1 soos volg vertaal: '. . . Aan die vir wie God die Vader geroep het... en deur Christus bewaar', pas dit beter by die konteks van die Judasbrief om dit te vertaal met: '. . en wie Hy vir Christus bewaar. .' (so bv Grundmann 1979: 23-4; Bauckham 1983: 19). Schelkle (1964: 146) beskryf hierdie samewerking tussen God en Christus treffend aan die hand van die volgende woorde:

Für die Christologie des Judas ist es selbstverständlich, daß das Heilshandeln Gottes in gleich wesentlicher Weise durch den Vater wie duch Christus sich ereignet, vielleicht mit der Akzentuierung, $\mathrm{da}$ der schöpferische Beginn beim Vater ist, die eschatologische Vollendung beim Sohn....

Judas verstrek min gegewens in verband met die Heilige Gees. Uiteraard moes die lesers oor heelwat meer buite tekstuele kennis rakende die rol en funksies van die Heilige Gees beskik het om Judas se kursoriese verwysings na $\mathrm{Hom}$ in vers 19 en 20 te kon verstaan. $\mathrm{Al}$ wat hy dan oor die Gees vermeld, is dat Hy nie teenwoordig is by mense wat hulle self buite die lesers se leefwêreld bevind nie, en dat die lesers in die Heilige Gees moet bid. Laasgenoemde opmerking impliseer dat die Heilige Gees wel by die lesers aanwesig is en dat Hy as skakel tussen hulle en God dien, aangesien Hy die kommunikasiekanaal tussen hulle (via gebed as een van die vernaamste uitdrukkingsvorme 
van die lesers se subjektiewe betrokkenhed binne dié leefwêreld) in stand hou.

God, Christus en die Heilige Gees bepaal volgens Judas die grense sowel as die inhoude van die leefwêreld waarbinne hy en die lesers hulle self bevind. Nie alleen orden hulle laasgenoemde se wêreld deur aan hulle ' $n$ bepaalde plek hierbinne toe te ken vanwaar hulle die realiteit as ' $n$ sinvolle totaliteit kan beleef nie, maar oefen aldus Judas ook beheer oor die verloop van gebeure hierbinne sowel as hierbuite uit. Die lesers sowel as diegene wat hulle buite eersgenoemde se wêreld bevind se eksistensie binne die empiriese realiteit sowel as hulle voortbestaan in die onsigbare sfeer hierna word naamlik uitsluitlik deur hulle verhouding tot God, Christus en die Heilige Gees bepaal.

Die engele neem volgens Judas ook 'n belangrike plek binne die simboliese universum as besondere diensknegte van God in, maar dan binne hulle eie toegewysde woonplek of magsgebied (arche ) in die onsigbare realiteit (vers 6). Hulle besit ongetwy feld ' $n$ hoër status as die mense. Een van die oortredings van die dwaalleraars was dan juis dat hulle die engele beledig het en nie hulle gesagsposisie erken het nie (Jud 1: 8). Binne die geledere van die engele kom daar ook 'n hiërargiese orde voor met Migael as (een van) die aartsengel(e) - vers 9. Judas meld dat hulle egter in alle opsigte ondergeskik aan God is, soos wat dit blyk uit die feit dat $\mathrm{Hy}$ in staat is om ongehoorsame engele in die donker dieptes gevange te hou (Jud 1: 6). Selfs die engel met die meeste mag, naamlik Migael, kan hom in sy woordestryd met Satan alleen op God se mag beroep as hy sê: 'die Here sal jou straf.'

\section{DIE HIËRARGIESE SOSIALE STRUKTUUR BINNE DIE BEDREIGDE SOSIALE WÊRELD}

Die lesers van die Judasbrief, en natuurlik Judas self, bevind hulle binne die leefwêreld (die kerk) wat deur bovermelde simboliese universum gelegitimeer word. Deur middel van 'n analise van die rolle wat hulle inneem, sowel as die gepaardgaande statusse wat hieraan gekoppel word, verkry ons (gedeeltelik) toegang tot hulle wêreld. Ten midde van die verskillende definisies wat deesdae aan pasgenoemde terme gekoppel word (vgl bv Hager, Haberland \& Paris 1973: 15 levv; Keesing 1975: 385), word in hierdie artikel by die meer tradisionele omskrywing van die terme status en rolle aangesluit. Status sou in hierdie verband dan omskryf kan word as die posisie wat ' $n$ individu in ' $n$ bepaalde 
sosiale sisteem inneem, terwyl rolle op hulle beurt weer verband hou met die reëls en sosiale verwagtinge wat aan 'n gegewe status gekoppel word (Turner 1972: 4; Funk 1981: 12-37). Geen rol figureer dus onafhanklik van die sosiale wêreld waarbinne dit aangetref word nie. Binne die leefwêreld wat die Judasbrief weerspieël, word die betrokkenes se rolle en hulle sosiale identiteit, soos reeds gesê, uitsluitlik deur hulle verhouding tot die bewoners van die simboliese universum bepaal. Hulle kennis van God, Christus en die Heilige Gees moet dan sin en betekenis aan hulle eksistensie verleen.

Die apostels bevind hulle self, wat status betref, as diegene met die meeste mag en aansien binne die kerk of leefwêreld van die lesers. Dit is hulle wat die Christelike geloof eens en vir altyd aan die lesers oorgelewer het - vers 2 (Hiebert 1985a: 46). Dit is ook hulle wat die lesers vroeër reeds teen die dwaalleraars gewaarsku het (vers 17-18). Vanweë die feit dat Judas in sy brief slegs na die apostels se optrede in die verlede verwys, ontstaan die vraag of hulle nog ten tye van sy skrywe fisies gelewe het. Teenstrydige antwoorde word op hierdie vraag verstrek. Reicke (1978: 212) meen byvoorbeeld dat Judas 'n geruime tyd na die apostels se optrede skryf; so ook Hahn (1981: 211) wat sê dat Judas in ' $n$ tydperk leef waar die apostoliese tradisie '... in seiner fundamentalen Bedeutung festgehalten und in seinem Bestand gesichert werde muss...' Bauckham (1983: 13) meen op sy beurt egter dat pasgenoemde tipe standpunt op ' $n$ foutiewe interpretasie van vers 17 berus waarvolgens genoemde vers op 'n reeds afgehandelde apostoliese era sou dui. Volgens hom wil Judas sy lesers slegs op die instruksies wat hulle vroeër tydens hul bekering van die apostels ontvang het, wys.

Vanweë die gebrek aan voldoende inligting is dit moeilik (en ook onnodig binne die parameters van hierdie artikel) om ' $n$ besliste keuse na enige kant toe te maak. Hoogstens sou ons kon sê dat die apostels ten tye van die skrywe nie meer dieselfde geografiese lokaliteit met die lesers gedeel het nie. Judas verwys dan, soos reeds gesê, slegs na die apostels se aktiwiteite in die verlede wat betrekking gehad het op die internalisasie en handhawing van die lesers se universum. Dit is met ander woorde hulle (as vernaamste significant others) wat aanvanklik die inhoude van die nuwe wêreld aan die lesers voorgehou het via die verkondiging van die evangelie (waardeur hulle die onsigbare hemelse realiteite aan die hand van simboliese taal by hulle hoorders teenwoordig gestel het). As normbronne (Segerstedt 1966: 96) het hulle ook aan die nuwe leefwêreld wat as gevolg van hulle prediking ontstaan het 'n 
bepaalde gestalte gegee deur die reëls vir legitieme gedrag hierbinne te bepaal en deur 'n nuwe sosio-religieuse struktuur en 'n eiesoortige religieuse taal daar te stel (vgl ook Joubert 1987: 19-27). Hiermee saam het hulle (volgens vers 17-18) vroeër ook 'n legitimerende funksie vervul deurdat hulle die simboliese kennis van hierdie realiteit in stand gehou en ook verdedig het teen ander bedreigende invloede van buite.

Naas die apostels neem Judas self ook 'n belangrike plek as significant other in die lesers se leefwêreld in. Hy identifiseer homself as broer van Jakobus, een van die erkende leiersfigure in die vroeë kerk en broer van Jesus (Kelly 1977: 232), asook as dienskneg van Jesus Christus (vers 1). Vanweë die kennis waaroor Judas aangaande die lesers se simboliese universum beskik, speel hy deur middel van sy brief as kundige en leiersfiguur ' $n$ belangrike rol in die handhawing hiervan te midde van die botsende interpretasies en opvattinge waaraan hulle blootgestel is. Sy doel met die skrywe is naamlik om:

- Hulle simboliese universum te handhaaf deur die presiese grense van hulle leefwêreld aan te dui,

- die korrekte handelswyse vir hulle binne die grense van hierdie wêreld te definieer - 'Legitimations indicate what is proper to do and what is not.' (McGaan 1980: 120) -, en

- om hulle eksistensie hierbinne as die enigste legitieme bestaanswyse binne die empiriese realiteit aan te dui.

Die lesers oor wie dit eintlik in die brief gaan (en wie die laagste posisie binne die hiërargiese struktuur in die kerk beklee, word eksplisiet as geliefdes (agapêtoi) aangespreek (vers $3 ; 17 ; 20$ ). Hierdie aanspreek vorm vind sy oorsprong in God se liefde vir hulle (vers 1). 'Die Existenz der Christen ist in die Liebe Gottes gegründet... Daß sie Geliebte Gottes sind, das bestimmt ihr Menschsein und qualifiziert es zum Christsein ...' (Grundmann 1979: 22). Hulle bevind hulself dus in 'n leefwêreld wat deur God se liefde omvat word. (Vergelyk afd 5 en 6 vir 'n verdere bespreking van die rolle van Judas en die lesers.)

Of hierdie lesers in een bepaalde gemeenteverband georganiseer was (Bauckham 1983: 16), en of Judas eerder ' $n$ aantal gemeentes (Schelkle 1964: 137) met sy skrywe in die oog gehad het, word nie eksplisiet vermeld nie. Gegee egter Judas se vermelding van dwaalleraars wat die lesers se midde binnegesluip het (vers 4) en spesifieke byeenkomste van hulle bygewoon het (vers 12), lyk dit tog asof die lesers wel dieselfde geografiese ruimte met mekaar gedeel en ook gesamentlike 
religieuse bymekaarkomste gehou het. Hulle sou dus as 'n gemeenskap of in religieuse terme as 'n gemeente geïdentifiseer kon word.

\section{DIE DWAALLERAARS WAT DIE LESERS SE SIMBOLIESE UNIVERSUM BEDREIG}

Judas wy die grootste gedeelte van sy brief (vers 4-16) aan 'n bespreking van die optrede van die dwaalleraars wat die gemeente binnegedring en hulle leerstellings en vreemde interpretasie van die realiteit hier kom versprei het. Alhoewel hy baie aandag aan hierdie persone afstaan, is hy vaag omtrent die presiese aard van hul gedrag en die inhoud van hulle leerstellings. Hy verlaat hom eerder op veralgemenings, eksemplariese voorbeelde uit die $\mathrm{Ou}$ Testament en die vroeg Joodse literatuur en op metaforiese beelde uit die natuur om hulle optrede mee te beskryf. Terwyl hy in vers 4-11 dan op ' $n$ bepaalde aspek van hulle optrede konsentreer, val die klem in vers $12-16$ vir hom veral '. . . auf das aüßere Auftreten der Häretiker ...' (Sellin 1986: 207).

Hierdie dwaalleraars was ' $n$ identifiseerbare groep persone wat die gemeente binnegesluip het (vers 4) en nog steeds dieselfde geografiese area met hulle gedeel het. Hulle skakel by die religieuse byeenkomste van die lesers in (vers 12), en sosialiseer skynbaar goed met hulle (vers 16). Judas beskryf hierdie mense as goddeloos (vers $4 ; 15 ; 17$ ). Hy motiveer dié stelling op verskeie maniere: Hulle misbruik God se genade as 'n rede tot immorele gedrag (aselgeia), hulle verloën Christus (vers 4), hulle beledig die engele (vers 8 ) en dinge waaroor hulle geen insig het nie (vers 10), hulle is skandvlekke by die liefdesmaaltye van die lesers (vers 12), hulle praat mense na die mond vir hulle eie gewin (vers 16), ensovoorts.

Hierdie groep mense moes hulle self wel as Christene geïdentifiseer het, anders sou hulle nie so geredelik die lesers se religieuse maaltye kon bywoon nie. Geloof in Christus was immers die belangrikste vereiste vir lidmaatskap binne die vroeë kerk (vgl afd 5). Hulle interpretasie van die aard en inhoude van die geloof verskil egter drasties van dié van Judas soos wat dit veral uit hulle gedrag blyk. Vanweë die vaagheid in Judas se beskrywing van hulle gedrag, en vanweë sy sterk aprioriese stellinginname teenoor hulle, is dit egter moeilik om 'n duidelike beeld hiervan te vorm. Waarskynlik het hulle die genade van God beskou: '. . . as a deliverance from all external moral constraint, so that the man who posesses the Spirit (v 19) becomes the 
only judge of his own actions ( $c f \mathrm{v}$ ) subject to no other authority ...' (Bauckham 1983: 11). Hiermee saam het hulle hulle moontlik ook nog beroep op allerlei profetiese openbarings (vers 8) ter regverdiging vir die immorele seksuele gedrag (Schrage 1973: 232; Eybers 1975: 117) waaraan hulle hulle sou skuldig gemaak het (verse $4 ; 8$ ).

Hierdie dwaalleraars se siening en kennis van God het dus tot gevolg dat hulle die grense van hul wêreld heelwat wyer trek as dié van Judas. God laat binne hul interpretasie van die wêreld enige vorm van gedrag toe aangesien $\mathrm{Hy}$ op grond van sy genade, of nie meer onderskei tussen korrekte en verkeerde gedrag nie, of verkeerde dade bloot net oor die hoof sien. Hiermee saam ontvang die dwaalleraars boonop nog visioene ter regverdiging vir hul afwykende gedrag, wat tot gevolg het dat hul gedrag in hul eie oë 'n religieuse dimensie verkry. Dit word immers deur direkte inspraak van God gesanksioneer. Op grond van hierdie visioene bestaan daar geen nodigheid of ruimte vir normbronne soos die apostels om die korrekte inhoude van die geloof vir hulle te artikuleer nie. Die engele neem ook geen belangrike posisie binne hulle leefwêreld in nie. Trouens, die dwaalleraars beledig hulle selfs (vers 8), waardeur hulle hierdie hemelwesens se rol en funksie totaal en al misken.

\section{6. 'VERVREEMDING' AS OORSAAK VIR DIE BEDREIGDING VAN DIE LESERS SE SIMBOLIESE UNIVERSUM}

Sou die lesers se eksistensie binne die simboliese universum wat deur Judas beskryf word, werklik in die gedrang wees, of waarsku Judas hulle bloot net teen 'n potensiële gevaar wat die dwaalleraars vir hulle in die toekoms mag inhou? Ter beantwoording van hierdie vraag, en met inagneming van die gevolgtrekkings waartoe in afdeling 4 afgekom is, naamlik dat hierdie mense met hulle (vir Judas) vreemde simboliese universum dieselfde fisiese ruimte met die lesers gedeel het en ook meegedoen het aan die religieuse aktiwiteite wat die gemeente se bestaan binne dié realiteit versimboliseer het, kan met goeie gronde aanvaar word dat hulle wel in reële bedreiging vir die lesers ingehou het. ' $n$ Moeiliker probleem om op te los, is egter om die oorsaak vir die feit dat die lesers wel persone met sulke afwykende beskouings en gedrag in hulle midde toegelaat het, te probeer vind. Die mees waarskynlike verklaring hiervoor sou dan wees om aan te neem dat 
hulle die inhoude en die grense van hul simboliese universum ietwat anders as Judas verstaan en beleef het.

Om nou enigsins ' $n$ idee te probeer vorm van die gemeente se selfbelewenis van die realiteit is redelik moeilik vanweë min konkrete gegewens in dié verband, maar by wyse van afleidings uit die beskikbare feite kan ons tog ' $\mathrm{n}$ algemene beeld vorm van

- die spesifieke aard van die gemeente as 'n groep met eie rolle en norme, en

- die mate waarin groeplede wel voldoen het aan die norme wat aan hulle voorgehou is. Die Grid/Group model wat deur die antropoloog Mary Douglas ontwikkel en deur Bruce Malina verfyn is (vgl egter ook Brown 1986: 68; Neyrey 1988: 76-7), dien in hierdie verband as ' $n$ belangrike en nuttige hulpmiddel ter verklaring vir die gemeente se gedrag jeens die dwaalleraars. Douglas (1970: 140-3) onderskei in haar ondersoek tussen sterk en swak groepe, waarvolgens eersgenoemde indicates high pressure to conform along with strong corporate identity, clear distinction between ingroup and outgroup, clear sets of boundaries separating the two, and a clear set of normative symbols defining, expressing and replicating group identity ...', terwyl laasgenoemde 'indicates low pessure to conform along with rather nebulous group identity (individualism), fuzzy distinctions between ingroup and outgroup, highly porous sets of boundaries between interfacing groups, and few or too many nonnormative symbols defining, expressing and replicating group identity ...' (Malina 1986: 14).

Sou die gemeente aan wie Judas skryf nou van naderby beskou word, lyk dit asof hulle:

(i) Oor geen duidelik geïdentifiseerde plaaslike leiersfigure beskik het wat die algemene riglyne ten opsigte van 'korrekte gedrag' kon neerlê en bedreigings teen hulle simboliese universum (wat deur die apostels aan hulle oorgelewer is) kon afweer nie. Judas identifiseer sy lesers bloot net as geliefdes (Jud 1: 1) sonder om in die aanhef of elders in die brief na die bestaan van enige leiersfigure te verwys. Indien sodanige persone wel binne die gemeente bestaan het, kan ons met redelike sekerheid aanvaar dat Judas eksplisiet na hulle sou verwys het vanweë die belangrike rol wat hulle as sy bondgenote ter legitimering van die bedreigde simboliese universum kon vervul. Dit beteken natuurlik nie dat daar per se geen 
leiersfigure in die gemeente was nie; die probleem is eerder dat daar oënskynlik geen leiers was wat presies dieselfde interpretasie van die realiteit as Judas gehandhaaf het nie. As gevolg van 'n gebrek aan hierdie tipe leiersfigure ontstaan die vraag in welke mate individue binne die gemeente gemeenskaplike behoeftes bo persoonlike behoeftes en sieninge sou gestel het en hoe sterk die sosiale beheer oor die algemene gedrag van die individue hierbinne was.

(ii) Wat die definiëring van grense tussen gemeentelede en buitestaanders betref, kan aanvaar word dat geloof in Christus as die belangrikste vereiste vir toetrede tot die gemeenteverband gegeld het. Op grond van hierdie geloofsverbondenheid aan Christus het die gemeente immers tot die geledere van die heiliges (hagioi) behoort (vers 3) wat hulle duidelik afgegrens het van diegene wat nie in Christus glo nie. Wat egter die fyner onderskeiding betref tussen diegene wat aan die geloofsinhoude soos deur die apostels oorgelewer (vers 3: 17) verbonde is en dié wat geloofsinhoude aanhang wat vreemd aan die apostoliese verkondiging is, blyk dit dat die lesers van die Judasbrief in gebreke gebly het om genoemde onderskeid te tref. Die dwaalleraars kon immers met hulle libertinistiese religieuse beskouinge en gedrag, wat strydig met die interpretasies van Judas en die apostels was, geredelik toegang tot die gemeente verkry. Dit wil dus voorkom asof daar:

* Òf geen normatiewe simbole binne die gemeente bestaan het wat die moreel-etiese aspekte van hulle gedrag binne die grense van hulle universum uitgestippel en gekontroleer het nie.

* Of dat die simbole wat wel in hierdie verband bestaan het nie normatiewe geldigheid besit het nie.

* Of dat die simboliese norme nie duidelik gedefinieer is nie.

* Oे dat dit, in aansluiting by punt (i) hierbo, nie voortdurend deur erkende leiersfigure aan hulle gekommunikeer is sodat sinvolle internalisasie hiervan by die lesers kon plaasvind nie.

In die lig van bovermelde gegewens lyk dit nie asof die lesers van die Judasbrief as 'n sterk groep volens Douglas se model beskou sou kon word nie (vgl ook Douglas 1970: 87). Die rede vir hierdie toedrag van sake is dat daar' $n$ verandering ten opsigte van die lesers se aanvanklike belewenig van 'the way things are' (Nineham 1976: 14) ingetree het, wat ons, vanuit Judas se perspektief, as 'n poses van vervreemding kan omskryf. McGaan (1980: 148-9) definieer genoemde begrip as '. . .a loss 
of the ability to participate in the constructive processes of the social world...', wat uiteraard verband hou met gebrekkige of mislukte legitimasie van ' $n$ bepaalde universum. 'Alienation is the failure of legitimation...' Die waardes en norme wat aan die lesers 'n veilige eksistensie binne hul leefwêreld moes waarborg, het met ander woorde nie meer effektief gefunksioneer nie sodat hulle fisiese eksistensie nie meer ' $n$ duidelike verifikasie van hulle betrokkenheid by die (nou bedreigde) simboliese universum was nie.

Vervreemding is 'n proses wat oor 'n tydperk geskied vanweë verskeie oorsake. In die geval van die lesers van die Judasbrief was die redes in punt (i) en (ii) hierbo aangevoer van deurslaggewende belang. Hierdie faktore, tesame met die blootstelling aan ' $n$ nuwe interpretasie van die realiteit, moes tot gevolg gehad het dat die geordende wêreld waarbinne hulle tot op hede veilig bestaan het, 'bevraagteken' is. Uit die inhoud en strekking van die brief lyk dit egter nie asof hierdie bevraagtekening 'n bewuste krities-rasionele proses was nie, maar eerder 'n geleidelike onbewuste wegbeweeg vanaf die simboliese sisteme van hulle wêreld met 'n gepaardgaande assimilasie van nuwe beskouinge (via die toelating van die dwaalleraars in hul midde). Wat wel soos 'n paal bo water staan, is dat die dwaalleraars geen probleem sou versoorsaak indien die gemeente se bestaande normatiewe sisteme hierdie blootstelling effektief kon identifiseer en neutraliseer nie.

Vervreemding beteken egter nog nie 'n breuk met die bestaande universum nie. Dit sou slegs gebeur as volledige hersosialisasie by die individu of groep plaasgevind het. 'In re-socialization ... the world of primary socialization is replaced by or assimilated within the new world ...' (Petersen 1985: 61). Judas veronderstel immers dat die lesers en hy steeds dieselfde leefwêreld en simboliese universum deel, dat hulle nog steeds deel van die kerk is selfs al sou daar sprake van vervreemding by laasgenoemde wees. Hy spreek hulle byvoorbeeld nog aan as geliefdes (vers $3 ; 17 ; 20$ ), hy verwys na die gemeenskaplike geloof wat hy met hulle deel (vers 3), hy praat ook van ons Here Jesus Christus (vers 4 ; 17) en van God ons Verlosser (vers 25).

\section{JUDAS SE POGINGS TER HANDHAWING VAN DIE BEDREIGDE SIMBOLIESE UNIVERSUM}

Judas tree binne die tekswêreld van die brief met die lesers in gesprek met die uitsluitlike doel om die bedreiging teen hulle simboliese 
universum af te weer. Sy eksplisiete identifikasie van homself as broer van Jakobus in vers 1 dien veral as 'n bewys van sy kundigheid en gesag (soos reeds in afd 2 aangetoon) wat aan hom die reg gee om hulle realiteit teen bedreigings van buite te verdedig. Enige gemeenskap maak immers van kundiges gebruik in die handhawing van hulle wêreld (Berger \& Luckmann 1975: 134). Hierdie persone (die sg experts) se taak is veral dan die daarstelling van ' $n$ teoretiese basis ter verduideliking van die inhoude van die wêreld, en om aan te toon dat '... the various 'meanings' of the society do in fact cohere rationally ...' (Nineham 1976: 14).

Om in pasvermelde doelwit te slaag, moet Judas aan die lesers wys wat hulle rol binne die wêreld is deur die verwagte handelswyses en verpligtinge wat hieraan gekoppel word (veral jeens God) duidelik uit te stippel. Hulle moet ook geleer word om die wêreld as 'n geordende geheel te besien, en 'they must be able to see how their actions fit into the pattern of things so that purposes can have desired consequences ...' (McGaan 1980: 52). Hy moet ook aan die lesers wys wat reg en verkeerd is, wie binne die universum tuishoort en wie buie gehou moet word.

Begin ons by laasgenoemde aspek, dan blyk dit uit die inhoud van die brief dat Judas geen moeite ontsien om die dwaalleraars se optrede in so 'n negatiewe lig as moontlik te stel nie. Hy vergelyk hulle optrede (in vers 5-12) eerstens met persone aan wie 'n uiters negatiewe konnotasie binne die Ou Testament en die vroeg Joodse literatuur gekoppel is: Die ongelowige Israeliete ten tye van God se verlossing van sy volg uit Egipte (bv Num 14: 11; 16:1-38), die engele wat met die mense vermeng het en gemeenskap met vroue gehad het (Gen 6: 1-4; 1 Henog 7-8 [Black 1985: 28-9; 125-9]), Sodom en Gomorra (Gen 19), Kain (Josefus: Ant 1. 52-6), Bileam (Num 31: 16) en Korag (Num 16: 1-35). Terselfdertyd meld Judas ook dat God hierdie persone wat hulself deur hul gedrag buite die raamwerk van Sy heil geplaas het, baie swaar gestraf het (vgl afd 3). Tweedens maak hy (in vers 12-13) ook gebruik van beelde uit die natuur wat verband hou met doodsheid en chaos (Magaß 1977 2: 34-47; Hiebert 1985b: 239-44) om die absolute illegitimiteit van die dwaalleraars se eksistensie aan te dui. Hulle is waterlose wolke, bome wat nie vrugte dra nie en tweemaal dood is, woeste golwe van die see, sterre wat van koers af is, ensovoorts.

Judas noem ook eksplisiet dat die dwaalleraars deur hulle libertinistiese optrede, wat gegrond is op hulle skeefgetrekte interpretasie van God en Christus (vgl afd 4), inderwaarheid eintlik besig is om God se 
genade te vertrap en Christus te verloën (Jud 1: 4). Hierdie persone maak hulle dus nie maar net skuldig aan die oortreding van sekere norme van hierdie universum nie, maar plaas hulleself deur hulle optrede en beskouinge volledig buite die sfeer hiervan. Blote fisiese deelname aan die aktiwiteite van die lesers se leefwêreld sonder om dieselfde inhoude aan die simboliese vorme (en kennis) wat laasgenoemde se wêreld in aansyn roep en legitimeer te gee, kan egter nie geduld word nie. Daarom noem Judas dat die hoof van hulle simboliese universum, naamlik God, self teen hierdie dwaalleraars optree deur tans vir hulle ' $n$ oordeel voor te berei (vers $4 ; 13$ ) en aan die einde van die tyd hulle in die poel van vuur te werp. God reageer volgens Judas dus op enige bedreiging teen die kerk deur middel van sy oordeelsmag soos wat die voorbeelde uit die Ou Testament ook heel treffend illustreer.

Wat die rol van die lesers betref, poog Judas as kundige om hulle huidige posisie as 'n swak groep (afd 4), vanweë die swak gedefinieerde grense tussen hulle en die dwaalleraars en hulle gebrek aan duidelike normatiewe simbole, te wysig na dié van 'n sterk groep waarbinne hierdie tekortkominge uitgeskakel is en waarbinne die groepslede die wêreld as 'n geordende en verstaanbare geheel beleef en hulle eie gedrag in ooreenstemming met die neergelegde norme hou. Laasgenoemde aspek wat die lesers se persepsie van die realiteit en hulle gepaardgaande gedrag hierbinne betref, omskryf Douglas (1970: $57)$ as die grid van 'n groep. Hierdie grid is hoog indien groepslede die wêreld beleef as 'coherent, consistent and entirely understandable in its broadest reaches', en laag indien die wêreld vir hulle onverstaanbaar voorkom (Malina 1986: 15; vgl ook bl 29-66).

Ter bereiking van hierdie doelwit omskryf Judas die verhouding tussen die lesers en God (as hoof van die universum) en die optrede wat van hulle binne dié verhouding verwag word in baie duidelike terme. Hy meld naamlik dat hulle God se eiendom is wat vir hom afgesonder (vers 3) is. Van hulle word nou verwag om in God se liefde te bly (vers 21), wat impliseer dat hulle Sy gebooie moet hou en nie soos die dwaalleraars Sy genade as 'n dekmantel tot ongehoorsaamheid misbruik nie. Judas se groot klem op God se eskatologiese oordeel ten opsigte van diegene wat nie aan Hom gehoorsaam bly nie, het juis ten doel om die lesers te waarsku wat die gevolge van sodanige misbruik van Sy genade en ongehoorsaamheid aan Hom is. Die lesers se verhouding tot Christus as hulle Kúrios en die Heilige Gees plaas ook 
bepaalde verpligtinge op hulle. Hulle moet naamlik volkome op die barmhartigheid van Christus hoop wat an hulle op die laaste dag wanneer Hy verskyn om die goddeloses te oordeel, die ewige lewe sal skenk (vers 21). Terselfdertyd moet hulle in die Heilige Gees bid (vers 20). Wat die engele betref, moet die lesers hulle respekteer en hulle nie beledig soos wat die dwaalleraars gedoen het nie (vers 8-9).

Indien daar nog enige onduidelikheid oor spesifieke inhoude van hulle geloof bestaan, ruim Judas dit uit die weg deur sy verwysing na die apostels (vers 17-18). Laasgenoemdes het die lesers vantevore reeds op die dwaalleraars gewys wat in die laaste dae slegs agter hulle eie goddelose begeertes sal aanloop. Die lesers moet nou opnuut weer aan die apostels (as sigbare grondleggers van hulle geloof en vernaamste interpreteerders van die inhoude daarvan) se woorde herinner word. Hulle moet hulleself ook in hulle allerheiligste geloof opbou (vers 20), wat prakties behels dat hulle aan die oorgelewerde apostoliese leerstellings wat hulle leefwêreld duidelik afgrens van dié van die dwaalleraars, moet vashou. Terselfdertyd moet die lesers hulle 'nuwe' kennis van die realiteit gebruik om hulle oor mense wat nog onder die dwaalleraars se invloed is te ontferm (vers 33-3) sonder om hulle aan hierdie mense se gedrag skuldig te maak. Hulle moet met ander woorde medeverantwoordelikheid vir die handhawing van hulle simboliese universum aanvaar deur die inhoude hiervan aan ander persone wat ook vervreemding ervaar te kommunikeer.

Dit blyk dat Judas groot nadruk plaas op die statusgeoriënteerde aard van die rolle wat binne hierdie bedreigde wêreld aangetref word sodat die lesers presies sal weet wat van hulle in hulle verhouding tot God, Christus, die Heilige Gees, die engele, die apostels en Judas self verwag word. Duidelike riglyne oor wat as korrekte gedrag en wat as illegitieme gedrag geklassifiseer sou word, word ook neergelê, terwyl streng sosiale beheer oor die gedrag van individue hierbinne uitgeoefen word '... through the referring of behaviour to the universal or particular norms which regulate the status' (dit is, van die lesers - SJ) (Berstein 1971: 155-6).

Geen ruimte vir interpretasies wat nie met dié van die lesers se normbronne en leiersfigure strook word toegelaat nie. Die wêreld wat Judas aan sy lesers voorhou is dus 'n geordende geheel waar elke persoon sy eie toegewysde plek en funksie het. Solank as wat hulle dan binne die grense van hierdie wêreld bly, ontvang hulle die gepaardgaande belonings wat met hierdie korrekte gedrag en gehoorsaamheid 
gepaard gaan (vers $2 ; 21$ ), maar sodra hulle hulle self deur hulle gedrag buite die afgebakende grense hiervan sou plaas, volg God se straf.

\section{SAMEVATTING}

Binne die tekswêreld omvorm Judas die beeld van sy lesers vanaf 'n swak groep na dié van 'n sterk groep met sterk statusgeoriënteerde rolle deur aan hulle en aan elke ander rol binne hulle universum 'n spesifieke plek te gee, deur hulle universum as die enigste legitieme bestaanswyse voor te hou, deur die grense tussen hulle en die dwaalleraars duidelik af te baken en deur die wêreld as 'n geordende geheel voor te hou waarbinne God diegene beskerm wat in Hom glo en ooreenkomstig Sy voorskrifte optee en andere straf wat dit nie doen nie.

Indien die lesers natuurlik nou die rolle wat aan hulle deur die loop van die tekswêreld voorgehou is, aanvaar en dit verinternaliseer, dan het die hele kommunikasiepoging in sy doel geslaag en dan is die aanslag teen die simboliese universum van Judas en sy lesers afgeweer. Judas twyfel egter geensins dat sy brief dié verlangde respons sal oplewer nie. Hy veronderstel immers reeds in die brief dat die implisiete lesers sy interpretasie van die realiteit aanvaar het, onder andere omdat hy hulle nou reeds kan versoek om ook ander mense wat onder die invloed an die dwaalleraars is te help deur hulle 'uit die vuur te ruk' (vers 23). Hy aanvaar ook dat God hulle van struikeling sal bewaar (deur te verhinder dat hulle onder die dwaalleraars se invloed sal beland) en heelhuids op die laaste dag Sy heerlikheid sal laat aanskou (vers 24). Daarom kan hy sy brief met 'n lofbetuiging aan God afsluit: 'Aan die enigste God, ons Verlosser deur Jesus Christus ons Here, aan Hom behoort die heerlikheid en die majesteit, die krag en die mag, van alle ewigheid af, ook nou en tot in alle ewigheid! Amen.'

\section{Literatuurverwysings}

BAUCKHAM, RJ 1983. Jude, 2 Peter. Waco, Texas: Word Books.

BERGER, PL \& LUCKMANN, T [1966] 1975. The social construction of reality. Middlesex:

Penquin.

BERNSTEIN, B 1971. Class, codes and control, Vol 1: Theoretical studies towards a sociology of language. London: Routledge \& Kegan Paul.

BEST, TF 1983. The sociological study of the New Testament: Promise and peril of a new discipline. SJTh 36, 181-94.

BLACK, M 1985. The book of Henoch or 1 Henoch. Leiden: Brill.

BOLKESTEIN, MH 1963. De brieven van Petrus en Judas. Nijkerk: Callenbach. 
BROWN, LJ 1986. Grid and group in Matthew's community: The righteousness/honor code in the sermon on the mount. Semeia 35, 61-91.

CONZELMANN, H \& LINDEMANN, A 1982. Arbeitsbuch zum Neuen Testament. 6 Aufl. Tübingen: Mohr.

DE VILLIERS, PGR 1982. Rennaisance van die sosiologiese teksanalise. ThEV 15, 19-32.

DOLEZEL, L 1985. Literary text, its world and its style, in Valdes, M) \& Miller, O (eds), Identity of the literary text, 189-203. Toronto: University of Toronto Press.

DOUGLAS, M 1970. Natural symbols: Explorations in cosmology. New York: Pantheon.

DOUGLAS, M 1975. Implicit meanings: Essays in anthropology. London: Routledge \& Kegan Paul.

DU PLESSIS, JG 1984. Some aspects of extralingual reality and the interpretation of texts. Neotestamentica $18,80-93$.

DU TOIT, CW 1987. Teks, verwysing, waarheid: Die relevansie van die verwysingskwessie vir die besinning oor die epistemologiese aard van die dogmatiek. Skrif en Kerk 8 , 154-169.

EYBERS, IH 1975. Aspects of the background of the letter of Jude. Neotestamentica 9, 113-23.

FISCHER, W \& MARHOLD, W 1978. Religionssoziologie als Wissenssoziologie. Stuttgart: Kohlhammer.

FRANKEMÖLLE, H 1987. 1 und 2 Petrusbrief. Judasbrief. Würzburg: Echter.

FUNK, A 1981. Status und Rolle in den Paulusbriefen: Eine Inhaltsanalytische Untersuchung zur Religionssoziologie. Innsbruck: Tyrolia.

GRUNDMANN, W 1979. Der Brief des Judas und der zweite Brief des Petrus. 2 Aufl. Berlin: Evangelische Verlagsanstalt.

HAGER, F, HABERLAND, H \& PARIS, R 1973. Soziologie \& Linguistik: Die schlechte Aufhebung sozialer Ungleichheit durch Sprache. Stuttgart: Metzlersche Verlagsbuchhandlung.

HAHN, F 1981. Randbemerkungen zum Judasbrief. ThZ 37, 209-18.

HAMILTON, P 1974. Knowledge and social structure: An introduction to the classical argument in the sociology of knowledge. London: Routledge \& Kegan Paul.

HIEBERT, DE 1985a. Selected studies from Jude, Part 1: An exposition of Jude 3-4. BiblSac $142,142-51$.

HIEBERT, DG 1985b. Selected studies from Jude, Part 2: An exposition of Jude 12-16. BiblSac 142, 238-49.

HIEBERT, DG 1985c. Selected studies from Jude, Part 3: An exposition of Jude 17-23. BiblSac 142, 355-66.

JOSEFUS 1927. Jewish antiquities, Vols 1-9. Greek text with English translation by HS Thackeray. Loeb Classical Library.

JOUBERT, SJ 1987. Die armoedeprobleem van die Jerusalemgemeente. 'n Sosio-historiese en eksegetiese ondersoek. DD-proefskrif, Universiteit van Pretoria.

KEE, HC 1980. Christian origins in sociological perspective. London: SCM.

KEESING, RM 1975. Explorations in role analysis, in Kinkade, MD, Hale, KL \& Werner, O (eds) Linguistics and anthropology: In honor of CF Voeglin, 385-404. Lisse: Peter De Ridder.

KELLY, JND [1969] 1977. A commentary on the epistles of Peter and Jude. London: A \& C Black.

KRAFT, CH 1979. Christianity in culture. Maryknoll: Orbis.

KUEMMEL, WG 1979. Introduction to the New Testament. 4th ed. Transl by HC Kee. London: SCM.

LATEGAN, BC 1985a. Some unresolved methodological issues in New Testment hermeneutics, in Lategan \& Vorster 1985: 3-26.

LATEGAN, BC 1985b. Reference, redescription and reality, in Lategan \& Vorster 1985: 67-94. 
LATEGAN, BC \& VORSTER, WS 1985. Text and reality: Aspects of reference in Biblical texts. Philadelphia: Fortress.

MAGAB, W 1973. Semiotik einer Ketzerpolemik am Beispiel von Judas 12f. LingBibl 19, 36-47.

MALINA, BJ 1986. Christian origins and cultural anthropology: Practical models for Biblical interpretation. Atlanta: John Knox.

McGAAN, LA 1980. Organizational reality: Elements in a constructivist sociology of communication in organizations. Ann Arbor: University Microfilms International.

MERRELL, F 1986. Structuralism and beyond: A critique of presuppositions, in Deely, J, Williams, B \& Kruse, FE, Frontiers in semiotics, 120-139. Bloomington: Indiana University Press.

NEYREY, JH 1988. Bewitched in Galatia: Paul and cultural anthropology. CBQ 50, 72-100.

NINEHAM, D 1976. The use and abuse of the Bible. Lndon: MacMillan.

PERELMAN, C 1979. The new rhetoric and the humanities: Essays on rhetoric and its applications. Translated by W Kluback. London: Reidel.

PETERSEN, NR 1985. Rediscovering Paul: Philemon and the sociology of Paul's narrative world. Philadelphia: Fortress.

REICKE, B 1978. The epistles of James, Peter and Jude. 8th ed. New York: Doubleday.

RICOEUR, P 1978. The rule of metaphor: Multi-disciplinary studies of the creation of meaning in language. London: Routledge \& Kegan Paul.

ROWSTON, DJ 1975. The most neglected book in the New Testament. NTS 21, 544-63.

SCHELKLE, KH 1964. Die Petrusbriefe: Der Judasbrief. 2 Aufl. Freiburg: Herder.

SCHRAGE, W 1973. Der Judasbrief, in Balz, H \& Schrage, W, Die Katholischen Briefe. Göttingen: Vandenhoeck.

SCROGGS, R 1980. The sociological interpretation of the New Testament: The present state of research. NTS 26, 164-79.

SEGERSTEDT, TT 1966. The nature of social reality: An essay in the epistemology of empirical sociology. Lund: Berlinska.

SELLIN, G 1986. Die Häretiker des Judasbriefes. ZNW 77, 206-25.

SORENSEN, HS 1970. Meaning and reference, in Greimas, AJ, Jakobson, R, Mayenowa, MR, Saumjan, SK, Stenitz, W \& Zolkiewski, S (eds), Sign, Language, Culture, 67-80. Paris: Mouton.

TURNER, JH 1972. Patterns of social organization: A survey of social institutions. London: Scott, Foresman \& Company.

VAN COLLER, HP 1985. Die semantiese aspek, in Cloete, TT, Botha, E \& Malan, C (reds), Gids by die literatuurstudie, 68-72. Pretoria: HAUM.

VORSTER, WS 1984. The historical paradigm: Its possibilities and limitations. Neotestamentica 18, 104-23.

VORSTER, WS 1985. Meaning and reference: The parables of Jesus in Mark 4, in Lategan \& Vorster 1985: 27-66. 